\title{
OPTIMALISASI KADER POSYANDU REMAJA GUNA MENGEMBANGKAN CHARACTER BUILDING DI KECAMATAN PAKAL
}

\author{
Aironi Zuroida ${ }^{1}$, Ardianti Agustin² \\ Fakultas Psikologi, Universitas Wijaya Putra
}

aironizuroida@uwp.ac.id, ardiantiagustin@uwp.ac.id

\begin{abstract}
Abstrak
Masa remaja merupakan masa storm and stress, karena remaja mengalami banyak tantangan baik dari diri mereka sendiri ataupun lingkungan. Apabila mereka tidak memiliki kemampuan untuk menghadapi berbagai tantangan tersebut, mereka dapat berakhir pada berbagai masalah salah satunya adalah masalah kesehatan. Berdasarkan hasil Survei Kesehatan Berbasis Sekolah di Indonesia tahun 2015 (GSHS) diketahui bahwa sebanyak 41,8\% laki-laki dan 4,1\% perempuan mengaku pernah merokok. Data yang sama juga menunjukkan 14,4\% lakilaki dan 5,6\% perempuan pernah mengkonsumsi alkohol. Gambaran faktor risiko kesehatan lainnya adalah didapatkan 8,26\% pelajar laki-laki dan 4,17\% pelajar perempuan usia 12-18 tahun pernah melakukan hubungan seksual. Character building merupakan suatu upaya untuk membangun dan membentuk akhlak dan budi pekerti seseorang menjadi baik. Pengabdian kepada masyarakat ini mempunyai tujuan untuk mengembangkan kemampuan remaja dalam upaya membangun karakter positif. Metode dalam pengabdian ini adalah dengan pemberian pelatihan tentang Character Building pada kader Posyandu Remaja. Tempat pelaksanaan kegiatan ini berada di kantor Kecamatan Pakal dan Puskesmas Benowo. Peserta dari pelatihan ini adalah kader posyandu remaja yang diambil dari beberapa sekolah di Kecamatan Pakal, baik sekolah SMP, SMA, maupun sekolah SMK yang berjumlah 25 anak. Sebelum dan sesudah petihan kader posyandu remaja diberikan evaluasi berkaitan dengan pemahaman Character Building. Materi yang disajikan dalam pelatihan ini berkaitan terdiri dari pemahaman tentang definisi dan faktor-faktor dari Character Building, cara-cara pembentukan karakter positif dan kemudian kader mempraktikan langsung. Setelah dilakukan pemberian pelatihan tentang Character Building terdapat peningkatan pengetahuan tentang Character Building, sehingga kader posyandu remaja dapat memahami akan pentingnya membangun karakter positif pada diri.
\end{abstract}

Kata Kunci : Optimalisasi, kader posyandu remaja, Character Building.

\section{PENDAHULUAN}

Masa remaja merupakan masa storm and stress, karena remaja mengalami banyak tantangan baik dari diri mereka sendiri ataupun lingkungan. Apabila mereka tidak memiliki kemampuan untuk menghadapi berbagai tantangan tersebut, mereka dapat berakhir pada berbagai masalah salah satunya adalah masalah kesehatan. Berdasarkan hasil Survei
Kesehatan Berbasis Sekolah di Indonesia tahun 2015 (GSHS) diketahui bahwa sebanyak 41,8\% laki-laki dan $4,1 \%$ perempuan mengaku pernah merokok. Data yang sama juga menunjukkan 14,4\% laki-laki dan 5,6\% perempuan pernah mengkonsumsi alkohol. Gambaran faktor risiko kesehatan lainnya adalah didapatkan $8,26 \%$ pelajar laki-laki dan $4,17 \%$ pelajar perempuan usia 12-18 tahun pernah melakukan hubungan seksual. Hal ini diperkuat oleh hasil

$$
\text { Pendidikan }
$$


penelitian yang dilakukan oleh Sumara, dkk (2017) bahwa kondisi masyarakat sekarang yang sudah begitu mengagungkan ilmu pengetahuan mengakibatkan kaidah-kaidah moral dan tata usila yang dipegang teguh oleh orang-orang dahulu menjadi tertinggal di belakang. Dalam masyarakat yang telah terlalu jauh dari agama, kemerosotan moral orang dewasa sudah lumrah terjadi. Kemerosotan moral, tingkah laku dan perbuatanperbuatan orang dewasa yang tidak baik menjadi contoh atau tauladan bagi anak-anak dan remaja berdampak timbulnya kenakalan remaja.

Remaja memiliki artian yang sangat luas dari segi fisik, psikologi, dan sosial. Secara psikologis remaja adalah usia seseorang yang memasuki proses menuju usia dewasa. Masa remaja merupakan masa dimana remaja tidak merasa bahwa dirinya tidak seperti anak-anak lagi dan merasa bahwa dirinya sudah sejajar dengan orang lain di sekitarnya walaupun orang tersebut lebih tua (Hurlock, 2011). Menurut Sarwono (2011) ada tiga tahap perkembangan remaja, yaitu : pertama, Remaja awal sering dikenal dalam istilah asing yaitu early adolescence memiliki rentang usia antara 11-13 tahun. Pada tahap ini mereka masih heran dan belum mengerti akan perubahan perubahan yang terjadi pada tubuhnhya dan dorongan-dorongan yang menyertai perubahan tersebut. Mereka juga mengembangkan pikiran-pikiran baru, mudah tertarik pada lawan jenis, dan juga mudah terangsang secara erotis. Kedua remaja madya, remaja yang dikenal dalam istilah asing yaitu middle adolescence memiliki rentang usia antara 14-16 tahun. Tahap remaja madya atau pertengahan sangat mebutuhkan temannya. Masa ini remaja lebih cenderung memiliki sifat yang mencintai dirinya sendiri (narcistic). Remaja pada tahap ini juga masih bingung dalam mengambil keputusan atau masih labil dalam berperilaku. Ketiga remaja akhir, remaja akhir atau istilah asing yaitu late adolescence merupakan remaja yang berusia antara 17-20 tahun. Masa ini merupakan masa menuju dewasa dengan sifat egois yaitu mementingkan diri sendiri dan mencari pengalaman baru. Remaja akhir juga sudah terbentuk identitas seksualnya. Mereka biasanya

\footnotetext{
Menyikapi banyaknya permasalahan baik yang berkaitan dengan kesehatan maupun
}

perkembangan remaja, Kementerian Kesehatan telah mengembangkan Pelayanan Kesehatan Peduli Remaja (PKPR) di Puskesmas. Salah satu program dari PKPR adalah Posyandu remaja. Dalam buku Petunjuk Teknis Penyelenggaraan Posyandu Remaja (2018) dijelaskan bahwa Posyandu Remaja adalah Pos Kesehatan Remaja atau sebuah wadah yang memfasilitasi remaja dalam memahami seluk beluk remaja selama masa puber dan ditujukkan kepada siswa dan remaja pada umumnya. Posyandu Remaja diharapkan dapat menjadi wadah untuk memfasilitasi remaja dalam memahami permasalahan kesehatan remaja, menemukan alternatif pemecahan masalah, membentuk kelompok dukungan remaja, memperluas jangkauan Puskesmas PKPR, terutama bagi remaja daerah yang memiliki keterbatasan akses.

Lickona, (2013), mengungkapkan kecanggihan teknologi dewasa ini sangat berpengaruh pada perkembangan nilai-nilai moral remaja. Orang tua dan pendidik harus dibekali dengan komponen karakter yang baik untuk tujuan aktualisasi kepribadian remaja yang sehat. Karakter terdiri dari nilai operatif, nilai dalam tindakan. Manusia berproses dalam karakternya, seiring dengan suatu nilai yang menjadi suatu kebaikan dan suatu disposisi batin yang dapat diandalkan untuk menanggapi situasi dengan cara yang menurut moral baik. Selanjutnya ia menambahkan bahwa karakter yang terasa demikian mempunyai tiga bagian yang saling berhubungan: pengetahuan moral, perasaan moral, dan tindakan moral. Pengetahuan moral meliputi: kesadaran moral, pengetahuan nilai moral, penentuan perspektif, pemikiran moral, pengambilan keputusan, dan pengetahuan pribadi. Perasaan moral mencakup: hati nurani, harga diri, empati, mencintai hal yang baik, kendali diri, dan kerendahan hati. Tindakan moral memiliki tiga aspek karakter, yaitu: kompetensi, keinginan, dan kebiasaan. Ketiga hal ini diperlukan untuk mengarahkan suatu kehidupan moral dan membentuk kedewasaan moral. Perlu dipikirkan jenis karakter yang diinginkan anak (remaja). Sudah jelas setiap orang menginginkan anak-anaknya mampu menilai apa yang benar, sangat peduli tentang apa yang benar, dan selanjutnya melakukan apa yang mereka yakini itu

$$
\text { Pendidikan }
$$


benar meskipun harus berhadapan dengan godaan dari dalam dan tekanan dari luar.

Berkaitan dengan hal tersebut Jamal Ma'mur Asmani (2012), mengungkapkan bahwa pendidikan karakter merupakan upaya-upaya yang dirancang dan dilaksanakan secara sistematis dalam rangka penanaman nilai-nilai perilaku manusia yang berkaitan dengan Tuhan Yang Maha Esa, diri sendiri, sesama manusia, lingkungan dan kebangsaan. Selanjutnya Supinah dan Parmi (2011) menjelaskan, pendidikan karakter bagi para remaja dapat menyaring informasi-informasi yang tidak sesuai bagi mereka. Informasi 'tidak layak' tersebut dapat diperoleh dari lingkungan sekolah, keluarga, bahkan lingkungan pertemanan. Apalagi dengan arus informasi, yang diakselerasi dengan kemajuan teknologi informasi yang begitu pesat. Proses internalisasi melalui berbagai sumber informasi yang diperoleh remaja, dapat mempengaruhi pola pola pikir dan dapat mewujud dalam bentuk tingkah laku maupun perbuatan. Urgensi pendidikan karakter sebagai sebagai salah satu upaya untuk meningkatkan kualitas sumber daya manusia diperkuat dengan kebijakan pemerintah melalui UU No. 20 tahun 2003 tentang Pendidikan Karakter yang diperkuat oleh Peraturan Presiden No 87 tahun 2017 tentang Penguatan Pendidikan. Turunan kebijakan tersebut merupakan upaya perwujudan cita-cita pembangunan karakter sebagaimana diamanatkan dalam Pancasila dan Pembukaan UUD 1945 serta mengatasi permasalahan kebangsaan saat ini, maka pemerintah menjadikan pembangunan karakter sebagai salah satu program prioritas pembangunan nasional. Pendidikan karakter ditempatkan sebagai landasan untuk mewujudkan visi pembangunan nasional, yaitu "mewujudkan masyarakat berakhlak mulia, bermoral, beretika, berbudaya, dan beradab berdasarkan falsafah Pancasila".

Beberapa karakter minimal yang perlu dikembangkan dalam kurikulum 2013 di antaranya seperti berikut. (1) Tangguh; perilaku yang menunjukkan upaya sungguh sungguh dalam mengatasi berbagai hambatan belajar dan tugas serta menyelesaikan tugas dengan sebaik baiknya. (2) Jujur; perilaku yang didasarkan pada upaya menjadikan dirinya sebagai orang yang selalu dapat dipercaya dalam perkataan, tindakan, dan pekerjaan. (3) Cerdas; mencari dan menerapkan informasi dari lingkungan dan sumber lain secara logis, kritis, dan kreatif. (4) Peduli; sikap dan tindakan yang selalu berupaya mencegah kerusakan pada lingkungan alam di sekitarnya, dan mengembangkan upaya upaya untuk memperbaiki kerusakan alam yang sudah terjadi, selalu ingin memberi bantuan bagi orang lain dan masyarakat yang membutuhkan (Suparno, 2018).

Proses pendidikan yang profesional dapat membentuk karakter pada peserta didiknya. Oleh karena itu dalam pelaksanaannya pendidikan karakter ini ber integrasi dengan pendidikan formal, informal, dan non formal agar dapat membentuk karakter positif khususnya di kalangan remaja. Sebab remaja masih berada dalam tahap pertumbuhan dan perkembangan yang memiliki kepribadian labil dan sedang mencari jati diri untuk membentuk karakter permanen. Pendidikan pada usia remaja menjadi momen yang penting dalam menentukan karakter seseorang setelah dewasa (Kristiawan, 2015).

$\begin{array}{clr}\text { Pembentukan kepribadian remaja } & \\ \text { berhubungan dengan banyak faktor yang }\end{array}$ memengaruhinya seperti melalui pendidikan dan pengendalian terhadap diri sendiri, kecerdasan emosional, lingkungan tempat berkatifitas/kerja, kondisi dan disiplin diri, kemampuan mengelola diri/emosi, kemampuan menghadapi situasi yang dihadapi, dan masih banyak lagi yang dapat mendukung pribadi. Maka untuk memperoleh hasil yang bermanfaat, artikel dibatasi pada hubungan antara pentingnya Character Building dalam membentuk kepribadian remaja melalui kegiatan Pengabdian Kepada Masyarakat.

\section{METODE}

Kegiatan pengabdian ini bertempat di Puskesmas Benowo. Yang dilaksanakan pada bulan Juli 2019 sebanyak dua kali pertemuan. Sasaran kegiatan ini adalah kader Posyandu Remaja Benowo yang berjumlah dua puluh lima orang dan berasal dari beberapa sekolah SMP, SMA dan SMK di Kecamatan Pakal.

Kegiatan dimulai dengan melakukan survey wilayah dan sasaran kegiatan, perijinan, dan sosialisasi dengan pihak Puskesmas terkait rencana kegiatan. Instrumen kegiatan yang dipersiapkan antara lain media pelatihan dan penyuluhan (Materi

$$
\text { Pendidikan }
$$


pelatihan, poster, software, dan alat tulis) dan peralatan. Publikasi dikonfirmasikan dengan ketua Puskesmas dan didistribusikan kepada kader Posyandu Remaja melalui media, undangan, dan pengumuman langsung. Persiapan lain meliputi konsumsi dan doorprize.

Kegiatan pelatihan Character Building pada kader Posyandu Remaja terdiri dari pemahaman tentang definisi dan faktor-faktor dari Character Building, cara-cara pembentukan karakter positif dan kemudian kader mempraktikan langsung terkait cara-cara tersebut. Evaluasi dilakukan dengan cara memberikan diberikan pretest dan posttest sebelum dan sesudah petihan dengan soal-soal yang berkaitan dengan pemahaman Character Building serta dilanjutkan dengan diskusi.

\section{HASIL DAN PEMBAHASAN}

\section{Pelatihan Character Building pada Kader Posyandu Remaja.}

Kegiatan pengabdian masyarakat ini telah diimplementasikan pada bulan Juli 2016. Pelatihan dilaksanakan dua kali pertemuan dan tiap pertemuan berlangsung selama dua jam. Peserta dalam pelatihan ini terdiri dari kader posyandu remaja yang berasal dari siswa SMP, SMA dan SMK di Kecamatan Pakal berjumlah dua puluh lima kader. Pelaksanaan pelatihan pertama bertempat di kantor Kecamatan Pakal, kemudian pada pelatihan kedua bertempat di puskesmas Benowo.

Sebelum memulai materi pelatihan, pembicara mengajak kader untuk berdiskusi terkait pemaham mereka tentang saat ini dan memberikan Pretest tentang pemahaman kader posyandu remaja mengenai character building. Melalui proses diskusi dan pretest tersebut terlihat bahwa sebagian besar kader posyandu remaja belum dapat memahami tentang Character Building, sehingga belum mampu memaksimalkan cara-cara efektif dalam proses membentuka karakter diri.

Kemudian pembicara memberikan pelatihan yang berkaitan dengan Character Building dan dibagi menjadi dua pertemuan dengan materi yang berisi tentang definisi dan faktor-faktor terbentuknya Character Building, cara-cara pembentukan karakter positif dan kemudian kader mempraktikan langsung terkait cara-cara tersebut. Setelah pemberian pelatihan kader posyandu remaja diberi posttest untuk melihat apakah ada peningkatan terhadap pengetahuan kader posyandu remaja berkaitan dengan Character Building agar dapat melihat sejauh mana kader posyandu remaja memperoleh manfaat dari pelatihan, apakah sudah dapat memahami materi dan kemudian mengaplikasikannya baik untuk diri sendiri ataupun untuk bisa dibagikan pemahaman tersebut terhadap teman-teman mereka.



Gambar 1. (Pelatihan character building pertemuan pertama)

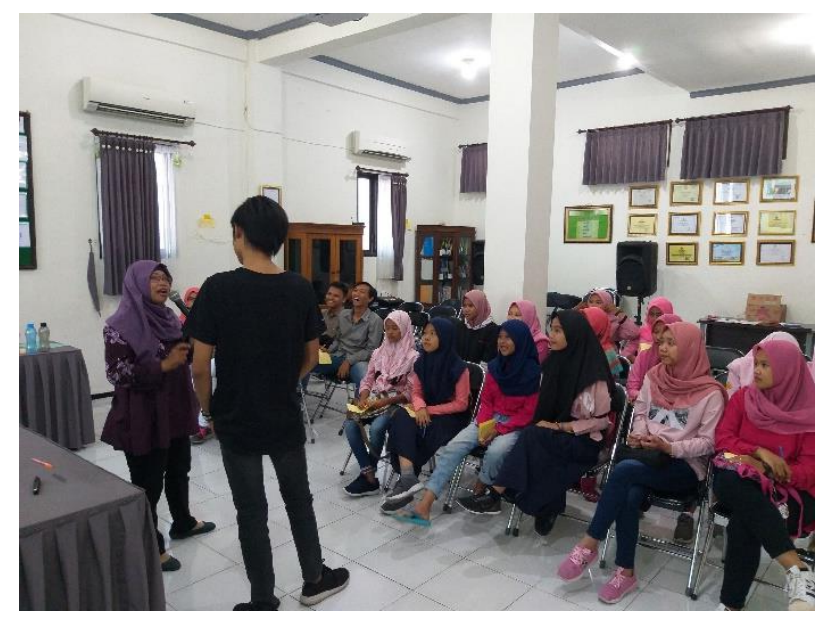

Gambar 1. (Pelatihan character building pertemuan kedua) 


\section{Hasil Evaluasi Pelatihan Character Building pada Kader Posyandu Remaja.}

Tingkat pengetahuan kader posyandu remaja tentang Character Building sebelum diberikan pelatihan adalah sebagai berikut:

Diagram 1. (Tingkat Pengetahuan Kader Posyandu Remaja Sebelum Pelatihan) PENGETAHUAN KADER POSYANDU REMAJA SEBELUM PELATIHAN

—Kurang —Cukup Baik

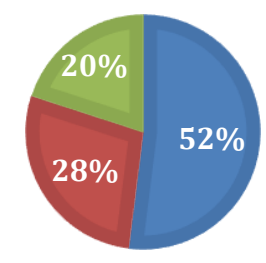

Berdasarkan diagram pie diatas, setelah dilakukan pengelompokkan tingkat pengetahuan, 5 remaja (20\%) dinyatakan memiliki pengetahuan baik tentang Character Building (skor penilaian 100 -76), 7 remaja (28\%) yang memiliki pengetahuan cukup tentang Character Building (skor 75 -56), dan 13 remaja (352\%) yang memiliki pengetahuan kurang tentang Character Building (skor 55-40).

Dari 25 pertanyaan yang diajukan sebelum pelatihan kepada kader posyandu remaja nampak bahwa jawaban dari setiap pertanyaan yang diberikan oleh kader tidak berkolerasi yaitu hanya pada pertanyaan - pertanyaan tertentu saja yang dapat dijawab dengan benar dan beberapa pertanyaan yang tidak dapat dijawab diantaranya berkaitan dengan pengertian Character Building serta cara-cara membangun karakter positif.

Sedangkan dari hasil evaluasi posttest, diketahui bahwa tingkat pengetahuan kader posyandu remaja tentang Character Building setelah diberikan pelatihan adalah sebagai berikut :
Diagram 2. Tingkat Pengetahuan Kader Posyandu Remaja Sesudah Pelatihan

PENGETAHUAN KADER POSYANDU REMAJA SEBELUM PELATIHAN

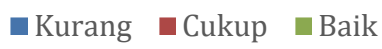

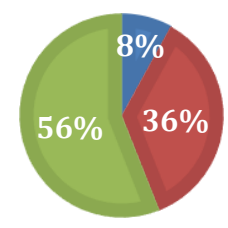

Setelah dilakukan pelatihan tentang Character Building, pengetahuan kader posyandu remaja meningkat menjadi berpengetahuan baik yaitu sebanyak 11 remaja (64\%) dan berpengetahuan cukup sebanyak 7 remaja (36\%). Sedangkan 2 remaja lainnya masih berada dalam kategori kurang (8\%).

Terjadinya peningkatan dalam pemahaman Character Building disebabkan karena remaja sudah mendapatkan informasi melalui pelatihan Character Building tentang definisi dan faktor-faktor dari Character Building, cara-cara pembentukan karakter positif dan praktik. Dengan demikian memberikan informasi dan pelatihan serta pendampingan yang baik akan memberikan kemudahan kader posyandu remaja untuk memperoleh pengetahuan yang baik tentang Character Building. Sesuai dengan pendapat Kristiawan (2015), bahwa pendidikan karakter ini ber integrasi dengan pendidikan formal, informal, dan non formal agar dapat membentuk karakter positif khususnya di kalangan remaja. Sebab remaja masih berada dalam tahap pertumbuhan dan perkembangan yang memiliki kepribadian labil dan sedang mencari jati diri untuk membentuk karakter permanen. Pendidikan pada usia remaja menjadi momen yang penting dalam menentukan karakter seseorang setelah dewasa.

\section{KESIMPULAN}

Berdasarkan pengabdian masyarakat yang sudah dilakukan yaitu berupa pelatihan character 
Building sebagai upaya ,mengoptimalkan kader posyandu remaja yang diberikan kepada 25 kader dari berbagai sekolah baik SMP, SMA mapua SMK. Diperoleh hasil bahwa terdapat peningkatan pemahaman pada kader posyandu remaja terkait Character Building, yakni $36 \%$ berada pada kategori cukup dan 56\% berada pada kategori Baik. Dengan diperolehnya peningkatkan pemahaman pada kader diharapkan sebagai kader posyandu remaja yang telah terpilih kedepannya dengan pemahaman yang telah diperoleh terkait Character Building dapat mereka salurkan kepada remaja-remaja lain dalam hal ini teman-teman mereka baik dilingkungan rumah maupun sekolah. Akan tetapi masih terdapat $8 \%$ remaja yang belum menunjukkan adanya peningkatan, sehingga pemahaman mereka masih berada dalam kategori kurang.

Dari hasil tersebut, maka saran untuk kegiatan selanjutnya agar lebih banyak ditambahkan materi praktek dan tugas rumah yang dievaluasi secara berkala. Mengingat pemahaman teoritisnya sudah diberikan pada pertemuan tersebut. Selain itu, diharapkan pelatihan membangun karakter juga diberikan kepada orangtua dan tenaga pendidik agar pola asuh di rumah dapat konsisten dan dijalankan dengan penuh komitmen bersama-sama antara orangtua, tenaga pendidik dan remaja.

\section{REFERENSI}

Referensi yang dimuat hanya yang disitasi dalam Asmani, Jamal Ma'mur. 2012. Buku Panduan Internalisasi Pendidikan Karakter di Sekolah. Yogyakarta : Diva Press.
Hurlock, Elizabeth B. (2011). Psikologi Perkembangan : Suatu Pendekatan Sepanjang Rentang Kehidupan. Jakarta : Erlangga.

Indonesia. Kementerian Kesehatan RI. Direktorat Jenderal Kesehatan Masyarakat Kementrian Kesehatan RI (2018). Petunjuk Teknis Penyelenggaraan. Jakarta :Kementrian Kesehatan.

Kristiawan, M. (2015, juni). Telaah Revolusi Mental dan Pendidikan Karakter Dalam Pembentukan Sumber Daya Manusia Indonesia yang Pandai dan Berakhlak Mulia. Ta'dib ,Volume 18 No.1.

Lickona, Thomas. 2013. Educating for Character (Mendidik untuk Membentuk Karakter). Terj. oleh Juma Abdu Wamaungo. Jakarta: Bumi Aksara.

Sarwono. 2011. Psikologi Remaja.Edisi Revisi. Jakarta: Rajawali Pers.

Sumara, Dadan \& Sahadi Humaedi, M. B. S. (2017). Kenakalan remaja dan penanganannya. Penelitian Dan PPM, 4(ISSN: 242-448X), 129-389.

Supinah dan Parmi. 2011. Pengembangan Pendidikan Budaya Dan Karakter Bangsa Melalui Pembelajaran Matematika di SD. Jakarta: Kemendiknas

Suparno, (2018) Analisis Faktor-Faktor Pembentuk Karakter Smart Siswa Di Sekolah Islam Terpadu. Jurnal Pendidikan Karakter tahun VIII. Nomor 1. 